DOI 10.37882/2223-2982.2020.07.01

\title{
ФОРМИРОВАНИЕ ИНТЕРЕСА ОБУЧАЮЩИХСЯ К ДИСТАНЦИОННОМУ ОБУЧЕНИЮ В УСЛОВИЯХ САМОИЗОЛЯЦИИ
}

\section{FORMATION OF STUDENTS ' INTEREST IN DISTANCE LEARNING IN CONDITIONS OF SELF-ISOLATION \\ U. Abdulkadirov}

Summary: The modern world makes its own adjustments in all spheres of human life. The emergence of new ways of obtaining information not only speeds up the process of obtaining it, but also forms a special culture, information. The development of students' cognitive abilities within the framework of improving information culture are one of the main tasks of modern education. The conditions of necessary self-isolation caused by the viral disease pandemic have become a challenge to the entire education system, as they have led to a temporary rejection of traditional forms of education, making distance learning methods the most effective means of teaching, if not the only one. The article considers the aspects of creating conditions for improving information literacy and increasing the cognitive interest of students in the conditions of necessary self-isolation.

Keywords: distance learning, self-isolation, information culture, cognitive interest, pedagogical process, information technologies.
В условиях стремительного развития пандемии и вынужденной необходимости перехода в режим самоизоляции, способы дистанционного обучения становятся основой педагогического процесса. Примером использования электронных образовательных технологий и дистанционного обучения в настоящее время может являться развернутая, практически во всех школах страны, системная платформа «Сетевой город». Цифровая площадка призвана создавать единое информационное образовательное пространство и осуществлять удаленные образовательные функции. Однако, как показала настоящая действительность, система не является достаточно эффективной. Попытки использования платформы для целей полнофункционального уровня дистанционного обучения, терпят неудачи. Стоит признать, что имеющиеся в настоящее время в стране электронные образовательные платформы недостаточно эффективны и слабо способны осуществить поддержание дистанционного учебного процесса на необходимом уровне. Причинами низкой функциональности лежат не только в различиях технических характеристик применяемого компьютерного оборудования, но, также в низкой готовности учащихся осуществить полноформатный переход к формам дистанционного обучения [8, с.163].
Абдулкадиров Умар Халович Аспирант, Чеченский государственный педагогический университет; Директор, МБОУ «Корен-Беноевская СШ» Курчалоевского муниципального района Чеченской Республики abdulkadirov-70@mail.ru

Аннотация: Современный мир вносит свои коррективы во все сферы жизнедеятельности человека. Появление новых способов получения информации не только ускоряет процесс её получения, но и формирует особую культуру, информационную. Развитие познавательных способностей школьника в рамках совершенствования информационной культуры является одной из главных задач современного образования. Условия необходимой самоизоляции, вызванные пандемией вирусного заболевания, стали вызовом всей системе образования, поскольку привели к временному отказу от традиционных форм обучения, выведя методы дистанционного обучения в разряд, если не единственных, то наиболее эффективных средств осуществления педагогической деятельности. В статье рассмотрены аспекты создания условий к совершенствованию информационной грамотности и повышения познавательного интереса учащихся в условиях необходимой самоизоляции.

Ключевые слова: дистанционное обучение, самоизоляция, информационная культура, познавательный интерес, педагогический процесс, информационные технологии.

Низкая эффективность электронных образовательных систем подвержена влиянию следующих факторов:

- незавершенность национального проекта «Образование». В рамках его реализации, в стране к 2024 году, должна быть создана современная и безопасная цифровая образовательная среда, способная обеспечить установленное качество и максимальную доступность образования всех видов и уровней [7];

- отсутствие доступа к сети «Интернет», например в удалённых населённых пунктах Северного Кавказа, Якутии, Дальнего Востока и.т.д;

- отсутствие актуального компьютерного оборудования, как со стороны преподавателей, так и со стороны учащихся. Здесь стоит отметить, что не все участники образовательного процесса имеют необходимое компьютерное оборудование, кроме того, эффективная дистанционная работа возможна в условиях обеспеченности достаточной пропускной способности Интернет-соединения;

- неготовность учащихся осуществлять выполнение учебных заданий в удалённом режиме;

- низкий уровень умений и навыков преподавателей во владении базовыми цифровыми продукта- 
ми, предназначенными осуществлять дистанционный учебный процесс [3, с.105].

Одной из причин обнаруженной неспособности школы осуществлять эффективный образовательный процесс в дистанционном режиме, наряду со слабой технической оснащённостью, а в отдельных случаях полного отсутствия таковой, является падение интереса самих учащихся получать знания. Подобный феномен достаточно нов и слабо освещен в педагогическом научном дискурсе. А между тем, образовательный процесс есть процесс взаимодействия, как преподавателя, так и самого обучаемого. Кроме того, значимую роль в этом учебном взаимодействии играет благоприятная домашняя среда. Роль родителей обучающихся, в поддержании необходимого уровня мотивации, стремлении освоить учебный материал в условиях изоляции, возрастает кратно. Именно в семье осуществляется закрепление мотивационных позиций, определяемых педагогом. Только совместными усилиями: школы, ученика, родителей, возможно достижения необходимого уровня мотивации и формирования устойчивого осознанного интереса ученика к обучению [2, с.73]. По нашему мнению, в случае отсутствия личностного контакта в системе: педагог - обучающийся - семья, образовательный процесс невозможен. Наоборот, в условиях активной информационной образовательной среды возможно формирование устойчивого познавательного интереса обучающихся [4, с.104]. Самоизоляция создала условия, когда уровень мотивации ученика, стал подвержен неизбежному ослаблению. Активно взаимодействующая информационная среда, будет не только поддерживать необходимую степень побудительных мотиваций, но и способна улучшить образовательный уровень.

Формирование основ информационной культуры и определения места в ней ученика, является одним из приоритетных направлений педагогического процесса. Знакомство с основными способами получения учебной информации, с последующим формированием устойчивых навыков применения цифровых образовательных платформ, должны закладываться еще на уровне начальной школы, что особенно важно, поскольку именно в этот период происходит становление психологической основы личности и формируется информационное мировоззрение [6, с.53]. В этом направлении эффективную работу проводит ЧИПКРО «Чеченский институт повышения квалификации работников образования». Такие проекты ЧИПКРО для начальной школы; «Будущее Чеченской Республики» и «Фестиваль исследовательских работ» втянули детей и родителей в процесс изучения и использования электронных образовательных ресурсов. Практика показала, что обучающиеся и родители, которые были приобщены к электронным образовательным ресурсам наиболее удачно и успешно стали работать в дистанционном режиме с электронными образо- вательными ресурсами.

Информационная среда, способствующая формированию устойчивой мотивации учащихся начальной школы, может состоять из трех взаимодействующих компонентов:

1. Деятельность педагога в границах образовательной программы. В рамках данного компонента может быть предусмотрено включение обязательного обучения основам работы с программно-аппаратным комплексом для формирования устойчивого навыка использования дистанционных образовательных технологий.

2. Внеурочная педагогическая деятельность. В рамках данного компонента, возможно, предусмотреть практическую работу, направленную на развитие и закрепление полученных знаний в области дистанционных образовательных технологий в сочетании с использованием электронных образовательных платформ.

3. Самостоятельная работа учащихся с обязательным привлечением родителей, в целях закрепления необходимых уровней практических навыков, а также достижения необходимой степени контроля над выполнением полученных дистанционно учебных заданий. Стоит подчеркнуть, что участие семьи в развитии дистанционных форм обучения является важной и неотъемлемой частью удалённого образовательного процесса.

Основными формами деятельности, направленной на формирование интереса, к дистанционному обучению могут быть:

- комплексное применение педагогических подходов. Основным, по нашему мнению будет являться личностно-ориентированный, поскольку в рамках его реализации возможно создание смыслообразующих мотивов [5, с.22]. В условиях реализации коммуникативного подхода, важным будет взаимодействие учащегося в образовательном пространстве. Реализация деятельностного подхода будет наиболее эффективна в условиях внеурочной педагогической деятельности;

- создание необходимых педагогических условий. К таким условиям стоит отнести учет индивидуальных психологических и возрастных характеристик учеников, а также, степень развития профессионально-значимых характеристик учителя.

Основными методами работы педагога, направленными на усиление мотивации учащихся к дистанционным учебным формам, может являться:

- активное взаимодействие обучаемых и обучающих, в информационно-образовательной среде, включая интерактивные формы. Подобное взаимодействие проходит стадии развития, от уровня 
ознакомления в условиях класса до самостоятельного использования технологий удаленного доступа к учебным платформам [1, с.81];

- применение способов передачи учебного материала от простой пересылки учебного материала на электронную почту учащихся до проведения полноценной он-лайн трансляции урока;

- стимулирование учебной деятельности обучаемых с применением педагогических условий цифровой образовательной среды в системе: педагог - ученик - семья;

- применение форм контроля. По нашему мнению, особенно важным будет создание как форм контроля в системе педагог - ученик, так и в системе ученик - семья. Итоговой целью будет создание условий для осуществления учащимся самостоятельного контроля над собственной учебной деятельностью.
Стоит отметить, что важным условием успешного применения дистанционного образования будет являться комплексная работа, как образовательного учреждения, так и учащегося и его родителей. Только в этом случае возможно формирование необходимых стимулов и системного трёхстороннего контроля над индивидуальным образовательным процессом.

Дистанционные методы образования не только способствуют совершенствованию информационной культуры учащихся и их родителей, но и требуют от педагога высокого уровня профессиональных компетенций, стремления формировать необходимый уровень личностного взаимодействия со своими учениками, поскольку только тогда возникают условия позволяющие формировать информационно-грамотную личность.

\section{ЛИТЕРАТУРА}

1. Брановский Ю.С., Беляева А. Работа в информационной среде. Высшее образование в России. 2002; 1: 81 - 87.

2. Додонов Б.И. 0 сущности интересов и подходе к их исследованию //Советская педагогика 1971. — № 9. — С. 72-82.

3. Ильина, Т.Ю. Проблемное обучение информатике младших школьников: диссертация .... кандидата педагогических наук - Санкт-Петербург, 1995. - 172 с.

4. Константинов Б.Б. Формирование основ информационной культуры младших школьников: диссертация ... кандидата педагогических наук - Москва, 2005. -273 C.

5. Маркова А.К. Формирование мотивации учения в школьном возрасте -- М.: Просвещение, 1983. - 96 с.

6. Магомеддибирова 3.А. Альбекхаджиева 3.Г. Формирование информационной культуры младших школьников // Мир культуры науки, культуры образования. Выпуск 57 / Горно-Алтайск, 2016 г. С.53-54

7. Паспорт национального проекта образование URL: https://base.garant.ru/72192486/. (Дата обращения: 03.05.2020).

8. Розина И.Н. Учебная компьютерно-опосредованная коммуникация: Теория, практика и перспективы развития. Университетская книга. $2003 ; 2: 160$ 175.

( Абдулкадиров Умар Халович (abdulkadirov-70@mail.ru). 